\title{
O próbach zbliżania światów - tłumacze i przekłady literatury polskiej w Brazylii
}

\author{
On Bringing Worlds Together - Translators and Translations of Polish Literature \\ in Brazil
}

Abstract: This paper is an attempt to narrate the history of translation of Polish literature in Brazil from the 1990s until today. It gives a detailed account of the translational achievements of the preeminent translators of Polish literature into Brazilian Portuguese, among them: Henryk Siewierski, Tomasz Barciński, Marcelo Paiva de Souza, Regina Przybycień, Piotr Kilanowski, and Eneida Favre. It also traces the interrelations between translational activities and scholarly research of the translators who are also academics working in the field of Polish literature. At the same time, the article attempts to highlight the importance of Polish studies in Paraná and of the Polish diaspora in popularizing Polish literature in Brazil.

Keywords: Brazilian translations of Polish literature, reception of Polish literature in Brazil, translation studies, Polish studies in Brazil

Streszczenie: Niniejszy artykuł jest próbą opowieści o historii przekładów literatury polskiej w Brazylii od lat dziewięćdziesiątych ubiegłego wieku po moment obecny. Zaprezentowano w nim szczegółowo dokonania translatorskie najważniejszych tłumaczy literatury polskiej na brazylijski portugalski, między innymi Henryka Siewierskiego, Tomasza Barcińskiego, Marcelo Paivy de Souzy, Reginy Przybycień, Piotra Kilanowskiego i Eneidy Favre. Starano się również ukazać powiązania między działalnością przekładową a badaniami naukowymi tych z tłumaczy, którzy zawodowo zajmują się badaniem literatury polskiej. Jednocześnie artykuł próbuje unaocznić ważną rolę polonistyki parańskiej i Polonii w popularyzowaniu literatury polskiej w Brazylii.

Słowa kluczowe: tłumaczenia literatury polskiej w Brazylii, recepcja literatury polskiej w Brazylii, translatologia, polonistyka w Brazylii

Literatura polska w Brazylii jest niewątpliwie coraz bardziej obecna. I bez wątpienia wielką część tej obecności zawdzięczamy bezpośrednio lub niebezpośrednio polskiej emigracji do Brazylii. Silna obecność potomków Polaków 
imigrantów, którzy do roku 1938 żyli w polszczyźnie i uczyli się jej w szkołach w Brazylii (do czasów zabronienia nauki i użytkowania publicznego języków mniejszościowych edyktem dyktatora Getúlio Vargasa, który spowodował prześladowania uczących i mówiących innymi językami niż portugalski ${ }^{1}$ ), stworzyła podwaliny pod zainteresowanie literaturą polską. To dzięki organizacjom polonijnym i wysiłkom Polonusów powstała na Uniwersytecie Federalnym Parany w Kurytybie (UFPR) w 2009 roku jedyna obecnie istniejąca w Ameryce Łacińskiej polonistyka, miejsce szczególne, jeżeli chodzi o upowszechnianie literatury polskiej i badania nad nią. To również głównie dzięki polskim imigrantom literatura polska zaistniała de facto w Brazylii.

Jednym z powodów przeprowadzki do Brazylii Henryka Siewierskiego, pioniera upowszechniania tu literatury polskiej, było właśnie badanie Polonii i współpraca z organizacjami polonijnymi ${ }^{2}$, a jednym z efektów tej współpracy stała się pierwsza antologia poezji polskiej wydana w Brazylii, Quatro poetas poloneses $^{3}$ (tłumaczenie wspólne z José Santiago Naudem), poprzedzona wydaniem prawie samizdatowym pierwszej antologii poezji polskiej w Portugalii ${ }^{4}$ (tłumaczenie wraz z grupą studentów). Wśród rozlicznych zasług Siewierskiego jako popularyzatora i tłumacza literatury polskiej, który sam stał się imigrantem, należy wymienić pionierskie czasopismo „Aproximaçóes: Europa do Leste em Língua Portuguesa"s, które redagował w latach 1987-1990 i w którego czterech zaledwie numerach zaistniały nie tylko ważne nazwiska z kręgu literatury polskiej (wymieńmy kilka z nich: Wisława Szymborska, Zbigniew Herbert, Czesław Miłosz, Ryszard Krynicki, Tadeusz Konwicki, Adam Zagajewski, Tadeusz Różewicz, Jan Błoński, Józef Tischner, Gustaw Herling-Grudziński, Witold Gombrowicz, Anna Kamieńska, Sławomir Mrożek, Leszek Kołakowski, Aleksander Wat, Ryszard Kapuściński), ale także ważne nazwiska z kręgu literatur słowiańskich i środkowoeuropejskich oraz nazwiska badaczy, których

1 Bardzo ciekawe studium przypadku Zjednoczenia Stowarzyszeń „Oświata” pokazanego na szerszym tle procesu wywołanego przez dekret Vargasa przedstawia historyk Polonii brazylijskiej Rhuan Targino Trindade Zaleski we wspólnym artykule z Fabianą Reginą da Silva: zob. F.R. da Silva, R.T.T. Zaleski, Estado Novo, campanha de nacionalização e a restrição nos processos de sociabilidade étnica entre os polono-brasileiros no Sul do Brasil: União das Sociedades Oswiata, „Revista Semina” 2017, t. 16, nr 2, Passo Fundo, http://seer.upf.br/index.php/ph/article/ view/8181/4836, dostęp: 6.04.2020.

2 Siewierski wspomina o tym w swej książce Jak dostatem Brazylię w prezencie, Kraków 1998, s. 9.

3 C. Miłosz, T. Różewicz, W. Szymborska, Z. Herbert, Quatro poetas poloneses, tłum., wstęp H. Siewierski, J.S. Naud, Curitiba 1994.

4 C. Miłosz, T. Różewicz, W. Szymborska, R. Krynicki, Z. Herbert, Versos polacos, tłum. M.T. Bação Fernandes, F. Menezes, M.C. Correia, C. Santos Pereira, H. Siewierski, Lisboa 1985.

5 „Aproximações: Europa do Leste em Língua Portuguesa”, Brasília: Lisboa, 1987-1990, t. 1-4. Skany czasopisma zostały niedawno udostępnione na stronie Katedry Cypriana Norwida prowadzonej przez Siewierskiego na Universidade de Brasília: http://catedranorwid.unb.br/ revista-aproximacoes, dostęp: 17.04.2020. 
późniejszy wkład w obecność literatury polskiej w Brazylii i badania nad nią powinien zostać tu odnotowany: Aleksandar Jovanović, Marcelo Paiva de Souza i niżej podpisany. Dziełem Jovanovicia są przede wszystkim przekłady rozlicznych wierszy poetów polskich (Jan Kochanowski, Julian Tuwim, Miłosz, Miron Białoszewski, Tymoteusz Karpowicz, Różewicz, Szymborska, Herbert, Bogdan Czaykowski, Zagajewski, Ewa Lipska, Julian Kornhauser, Stanisław Barańczak) w wydanej przez niego antologii poezji słowiańskiej Céu vazio ${ }^{6}$ I choć w odróżnieniu od Marcelo Paivy de Souzy i niżej podpisanego Jovanović (profesor na Universidade de São Paulo) nie jest badaczem literatury polskiej, niewątpliwie jego tłumaczenia do takich badań są używane.

Wróćmy do Siewierskiego (profesora na Universidade de Brasília) i jego zasług nie tylko jako propagatora literatury polskiej, jej badacza i inspiratora, który wielu badaczy i tłumaczy zainteresował tą literaturą, ale przede wszystkim jako tłumacza. Oprócz wymienionych już antologii Siewierski jest również tłumaczem tomiku poezji Miłosza (wespół z de Souza) ${ }^{7}$, dzieł zebranych Brunona Schulza ${ }^{8}$, Barbarzyńcy w ogrodzie Herberta ${ }^{9}$, Początku ${ }^{10}$ i Mszy za miasto Arras $^{11}$ Andrzeja Szczypiorskiego, Panny Nikt ${ }^{12}$ Tomka Tryzny, Swiata „opery żebraczej"Bronisława Geremka ${ }^{13}$, esejów Stanisława Lema ${ }^{14}$, Fortepianu Szope$n a^{15}$ Cypriana Kamila Norwida (ponownie wraz z de Souza) i trzeciego tomu O co pytaja nas wielcy filozofowie ${ }^{16}$ Kołakowskiego. Dodać należy, że Siewierski również tłumaczy na język polski i dzięki jego tłumaczeniu mamy po polsku

6 A. Jovanović, Céu vazio. 63 poetas eslavos, oprac., wstęp, przypisy, tłum. A. Jovanović, São Paulo 1996. Przełożone wiersze to: Kochanowskiego Ku muzom, O żywocie ludzkim, Na lipę; Tuwima Wiersz; Miłosza fragment Do Tadeusza Różewicza, poety, Piosenka o końcu świata, Ars poetica; Białoszewskiego Autoportret odczuwany; Karpowicza Pożar, Sen; Różewicza Kto jest poeta, Powrót poety, Rehabilitacja pośmiertna; Szymborskiej Niebo; Herberta Raport z oblężonego miasta, Czaykowskiego Bunt wierszem; Zagajewskiego Klęska; Lipskiej - Testament, Ucz się śmierci; Kornhausera Poezja; Barańczaka Dtugowieczność oprawców.

7 C. Miłosz, Não mais, wybór, tłum., wstęp H. Siewierski, M.P. de Souza, Brasília 2003.

8 B. Schulz, Ficção completa, tłum., posłowie H. Siewierski, São Paulo 2012. Jest to wznowienie poprawionych tłumaczeń z lat dziewięćdziesiątych (tenże, Sanatório, Rio de Janeiro 1994; tenże, Lojas de canela, Rio de Janeiro 1996). W zeszłym roku ukazało się kolejne poprawione wznowienie Sklepów cynamonowych (tenże, Lojas de canela e outras narrativas, São Paulo 2019).

9 Z. Herbert, Um bárbaro no jardim, tłum. H. Siewierski, Belo Horizonte 2018.

10 A. Szczypiorski, A bela senhora Seidenman, tłum. H. Siewierski, São Paulo 2007.

11 Tenże, Uma missa para a cidade de Arras, tłum. H. Siewierski, São Paulo 2001.

12 T. Tryzna, Senhorita Ninguém, tłum. H. Siewierski, Rio de Janeiro 1999.

13 B. Geremek, Os filhos de Caim. Vagabundos e miseráveis na literatura européia 1400 1700, tłum. H. Siewierski, São Paulo 1995. Paulo 2019.

14 S. Lem, Nova cosmogonia e outros ensaios, tłum., wstęp, posłowie H. Siewierski, São

15 C.K. Norwid, O piano de Chopin, tłum. H. Siewierski, M.P. de Souza, Brasília 1994.

16 L. Kołakowski, Sobre o que nos perguntam os grandes filósofos, t. 3, tłum. H. Siewierski, Rio de Janeiro 2009. 
między innymi jedyną książkę poetycką, którą wydał za życia Fernando Pessoa $^{17}$ i jedyną książkową antologię poezji brazylijskiej ${ }^{18}$.

Wśród najważniejszych dzieł Siewierskiego jako badacza literatury polskiej znajduje się niewątpliwie jego História da Literatura Polonesa ${ }^{19}$. Książka ta jest jednym z podstawowych podręczników używanych na polonistyce UFPR zarówno przez studentów, którzy polskiego jeszcze nie umieją, jak i przez tych, którzy pomimo tego, że ten język już znają, zawsze będą się posługiwać bieglej językiem ojczystym. Dodatkowym atutem historii literatury napisanej przez tłumacza jest to, że zilustrowana jest rozlicznymi przekładami Siewierskiego, de Souzy albo obydwóch translatorów pracujących w duecie. Innym ważnym przyczynkiem do badań jest jedyna miniantologia tekstów Mickiewicza i o Mickiewiczu ${ }^{20}$, będąca nadal jednym z podstawowych źródeł informacji na temat wieszcza i jego tekstów w Brazylii. Podobnym i ważnym dziełem stworzonym z udziałem Siewierskiego i de Souzy jest również wydawnictwo poświęcone Tuwimowi ${ }^{21}$.

Niewątpliwie pionierskie wysiłki tłumacza i badacza takiego jak Siewierski owocują rozlicznymi inspiracjami; tak jak same tłumaczenia stanowią bazę dla pracy badawczej nad literaturą polską. Oprócz wymienionych już przykładów wpływu, jaki jego prace wywarły na tłumaczach (jak Jovanović) czy tłumaczach będących również badaczami (jak de Souza), pozwolę sobie przytoczyć jeszcze dwa przejawy oddziaływania tłumacza i znawcy literatury Siewierskiego. Pierwszy z nich to obecność polskich wierszy w antologii poezji tłumaczonej autorstwa jednego z najwybitniejszych współczesnych poetów i tłumaczy brazylijskich Nelsona Aschera. Pomimo nieznajomości polskiego wielojęzyczny poeta, używając przekładów na różne języki i konsultując wątpliwości z Siewierskim, umieścił w swej antologii wiersze Mikołaja Sępa Szarzyńskiego, Miłosza, Karpowicza,

17 F. Pessoa, Przestanie, tłum. H. Siewierski, A. da Silva, Warszawa 2006.

1833 wiersze brazylijskie: Carlos Drummond de Andrade, João Cabral de Melo Neto, Mario Quintana, oprac. H. Siewierski, Warszawa 2011.

19 H. Siewierski, História da Literatura Polonesa, Brasília 2000.

20 Adam Mickiewicz: um poeta peregrino, oprac. H. Siewierski, Brasília 1998. Publikacja oprócz artykułów autorstwa między innymi Siewierskiego i de Souzy zawiera tłumaczenia autorstwa między innymi Siewierskiego (tłumaczenie na polski wiersza Castro Alvesa Do matki niewolnika, będącego parafrazą Do Matki Polki Mickiewicza), Mariano Kawki (Inwokacja do Pana Tadeusza), Paulo Leminskiego (*** polały się łzy me czyste), Machado de Assisa (Alpuhara), Marcelo Paivy de Souzy (Dzień dobry, Dobranoc, Stepy akermańskie, Ajudah), José Santiago Nauda (Nad wodq wielkq i czysta), Pawła Hejmanowskiego (fragmenty Ziemi Ulro Miłosza), Piotra Kilanowskiego i João Vianneya Cavalcanti Nuto (fragmenty Czarnych kwiatów Norwida).

21 Tuwim, oprac. A. Drewno, Warszawa 2013. Publikacja zawiera między innymi artykuł Wojciecha Ligęzy i przekłady autorstwa Siewierskiego (Erotyk, Wiersz, Los), de Souzy (Trawa, Abecadto, Ptasie plotki, Pan Tralaliński, Spóźniony stowik, Zosia samosia), Carlosa Drummonda de Andrade (Pogrzeb), Geira Camposa (fragment Kwiatów polskich), Aleksandara Jovanovicia (Wiersz), José Carlosa da Costy Diasa i Gerardo Beltrana (Lokomotywa) i André de la Cruza (Okulary). 
Szymborskiej i Herberta ${ }^{22}$. Zresztą podobną rolę w popularyzacji poezji polskiej przy pomocy znanego poety brazylijskiego, toute proportion gardée, odegrała dekadę wcześniej Grażyna Drabik, której tłumaczenia Szymborskiej, Kamieńskiej, Miłosza i Herberta we współpracy z wielką poetką brazylijską Aną Cristiną César należą do pierwszych tłumaczeń polskich poetów na portugalski i ostatnich dzieł poetki brazylijskiej ${ }^{23}$.

Drugim przykładem inspiratorskiej skuteczności Siewierskiego jest wpływ, jaki wywarł on na działalność Tomasza Łychowskiego, kolejnego z polskich imigrantów, zajmujących się rozpowszechnianiem kultury i literatury polskiej. Łychowski, urodzony w 1934 roku w Angoli w rodzinie polsko-niemieckiej, był jednym z najmłodszych więźniów Pawiaka i po wojnie wraz z rodziną wyemigrował do Brazylii, gdzie stał się jednym z aktywnych działaczy polonijnych ${ }^{24}$. Po przejściu na emeryturę mógł w pełni poświęcić się zainteresowaniom artystycznym. Obecnie jest malarzem, poetą (wspierał go zresztą przy pierwszych próbach poetyckich właśnie Siewierski) i tłumaczem. Dzięki inspiracji Siewierskiego Łychowski przełożył (oprócz utworów własnych - jest pisarzem dwujęzycznym) dwa pierwsze tomy esejów Kołakowskiego ${ }^{25}$ (trzeci tom, jak nadmieniłem, przetłumaczył sam Siewierski), niedawno zaś ukończył tłumaczenie Tryptyku rzymskiego Karola Wojtyły, który czeka na publikację w wydawnictwie É realizaçóes. Łychowski ogłosił również drukiem tłumaczenia wierszy Krynickiego i Lipskiej w czasopiśmie „Revista Brasileira” ${ }^{26}$.

Prawie równolatkiem, imiennikiem i przyjacielem Łychowskiego z młodzieżowej organizacji polonijnej w Rio de Janeiro „Świetliki” był Tomasz Barciński (1936-2014), kolejny imigrant, którego zasług dla upowszechniania w Brazylii literatury polskiej nie sposób przecenić. Jego rodzice, AK-owcy, uciekając przed prześladowaniami ze strony reżimu komunistycznego, przybyli do

22 N. Ascher, Poesia alheia. 124 poemas traduzidos, oprac., tłum. N. Ascher, Rio de Janeiro 1998. Przełożone wiersze to: Sępa Szarzyńskiego Epitafium Rzymowi; Miłosza Dziecię Europy i List; Karpowicza Lekcja ciszy; Szymborskiej Terrorysta, on patrzy; Herberta Tren Fortynbrasa.

23 Dokonania te jak dotąd niestety nie doczekały się wydania książkowego ani szczegółowego opracowania. Zacytujmy jedynie niektóre z publikacji umieszczonych w czasopismach: wiersze Kamieńskiej, Miłosza i Szymborskiej we wspólnym tłumaczeniu Grażyny Drabik i Any Cristiny César ukazały się w czasopiśmie „Religião e sociedade” 1984, nr 11, wiersze Herberta w „Folhetim”, 4.08.1985, s. 12.

${ }^{24} Z$ historią Łychowskiego, wspaniale opowiedzianą przez niego samego, można zapoznać się, czytając jego autobiografię: T. Łychowski, Moja droga na księżyc, Warszawa 2010.

25 L. Kołakowski, Sobre o que nos perguntam os grandes filósofos, t. 1, tłum. T. Łychowski, Rio de Janeiro 2009; tenże, Sobre o que nos perguntam os grandes filósofos, t. 2, thum. T. Łychowski, Rio de Janeiro 2009.

26 T. Łychowski, Poesia da Polônia: Ewa Lipska, Ryszard Krynicki „Revista Brasileira” 2016, t. 89, s. 245-265 (wiersze Lipskiej: Przestanie, Zdobądź się wreszcie, ${ }^{* * *}$ (Nie zostałem wybitnym mężem stanu), ${ }^{* * *}$ (Nie uratowała mnie powódź), Ucz się śmierci i Krynickiego: Moja córeczka uczy się czytać, Czym jest poezja, która nie ocala Narodów ani ludzi?, Wierzę, Dobroć jest bezbronna, Poezja). 
Brazylii w 1947 roku. Po przejściu na emeryturę w 1999 roku były inżynier postanowił poświęcić się tłumaczeniu literatury polskiej. Dzięki swoim kontaktom w dużych wydawnictwach i uporowi zdołał przetłumaczyć i wydać, w ciągu piętnastu lat aktywności, 24 książki. I pomimo że jakość tłumaczeń Barcińskiego często jest przyczynkiem do rozważań z dziedziny krytyki przekładu, pomimo że często możemy pokazywać na przykładach jego prac, czego tłumacz nigdy nie powinien robić i na jakie błędy nie może sobie pozwalać, pomimo utyskiwań tych, którzy, mając dostęp do oryginałów, porównują je z przekładami z niezmiennym zdziwieniem i zaskoczeniem (niestety nie pozytywnym), należy pionierską i tytaniczną pracę Barcińskiego zakwalifikować jako fenomen ze wszech miar pozytywny dla literatury polskiej.

Dzięki jego uporowi i przecieraniu szlaków wcześniej nieprzetartych zaistnieli na rynku brazylijskim autorzy polscy znani i nieznani, ważni i mniej ważni, sprzedający się dobrze i zalegający półki. I, co warto podkreślić, mimo że na jego błędy tłumaczeniowe zżymają się mniej lub bardziej oficjalnie znawcy tematu, nauczyciele i studenci polonistyki, to zaskakująca bywa bardzo pozytywna recepcja tłumaczeń Barcińskiego wśród tych, którzy owych niedociągnięć nie potrafią wytropić. Wielokrotnie słyszałem od kolegów na różnych brazylijskich uczelniach wyrazy zachwytu na temat książek Gombrowicza $^{27}$ i Kapuścińskiego ${ }^{28}$, zaistniałych po portugalsku dzięki Barcińskiemu. Podobne wypowiedzi docierały do mnie od młodszych czytelników zafascynowanych tłumaczeniami Andrzeja Sapkowskiego ${ }^{29}$. I tego rodzaju manifestacje znaczą jasno, że te książki się wybroniły.

27 W. Gombrowicz, Ferdydurke, tłum. T. Barciński, Rio de Janeiro 2006; tenże, Cosmos, tłum. T. Barciński, Rio de Janeiro 2007; tenże, Pornografia, tłum. T. Barciński, Rio de Janeiro 2009 .

28 R. Kapuściński, Ébano, tłum. T. Barciński, Rio de Janeiro 2002; tenże, O imperador, tłum. T. Barciński, Rio de Janeiro 2005; tenże, Minhas viagens com Heródoto, tłum. T. Barciński, Rio de Janeiro 2006; tenże, A guerra do futebol, tłum. T. Barciński, Rio de Janeiro 2008; tenże, $O$ xá dos xás, tłum. T. Barciński, Rio de Janeiro 2012. Wedle informacji pochodzących od Barcińskiego ukończył on również przekład książki Jeszcze dzień życia, nie ukazała się jednak ona po jego śmierci w odróżnieniu od innych tłumaczeń, które ukończył, a które zostały opublikowane pośmiertnie.

29 A. Sapkowski, $O$ último desejo, tłum. T. Barciński, São Paulo 2011; tenże, $A$ espada do destino, tłum. T. Barciński, São Paulo 2012; tenże, O sangue dos elfos, tłum. T. Barciński, São Paulo 2013; tenże, Tempo do desprezo, tłum. T. Barciński, São Paulo 2014. Przekład cyklu Sapkowskiego po śmierci tłumacza został ukończony przez Olgę Bagińską-Shinzato, brazylianistkę na UW, która przetłumaczyła brakujące cztery pozycje, wydane w Brazylii w pięciu książkach: tenże, Batismo de fogo, tłum. O. Bagińska-Shinzato, São Paulo 2015; tenże, A torre de andorinha, tłum. O. Bagińska-Shinzato, São Paulo 2016; tenże, A senhora do lago, t. 1, tłum. O. Bagińska-Shinzato, São Paulo 2017; tenże, A senhora do lago, t. 2, tłum. O. Bagińska-Shinzato, São Paulo 2017; tenże, Tempo de tempestade, tłum. O. Bagińska-Shinzato, São Paulo 2019. 
Próżno rozważać, co by było, gdyby takich stylistów jak Henryk Sienkiewicz $^{30}$, Sapkowski, Gombrowicz czy Kapuściński przełożył ktoś o większych umiejętnościach i swadzie językowej. W związku z tym, pomimo wcześniej wyrażonych wyrazów krytyki pod adresem braków, które widzę jako tłumacz i badacz, wolę skupić się na fenomenie człowieka, z determinacją poświęcającego swój czas na przekładanie literatury na język nieojczysty, starającego się pokazać w miejscu, które wybrał do życia, bogactwo kultury swego języka ojczystego. Tylko dzięki syzyfowej pracy i determinacji mogły zaistnieć po portugalsku takie dzieła, jak Trylogia Sienkiewicza czy Faraon Bolesława Prusa ${ }^{31}$. Tylko dzięki takiemu właśnie dzieleniu się pasją i próbie przybliżenia kultury ojczystej ojczyźnie wybranej mieliśmy w Brazylii Biegunów Olgi Tokarczuk ${ }^{32}$ na sześć lat przed Noblem. Tylko dzięki Barcińskiemu Kapuściński ${ }^{33}$ i Gombrowicz zostali wydani przez najważniejsze wydawnictwo w Brazylii i znani oraz doceniani są dość powszechnie. Na tyle, że być może kiedyś ktoś zapragnie wydać ich ponownie, w lepszym tłumaczeniu.

Praca tłumacza jest samotna i niewdzięczna, jest zmaganiem się z niemożliwością. Jeżeli do wpisanej w tę pracę niemożliwości pełnego przekładu oryginału dodamy niemożliwość kompletnego opanowania języka wybranej ojczyzny, ciągłe poruszanie się odrobinę po omacku, stałą potrzebę konsultacji z rodzimymi użytkownikami języka docelowego, może łatwiej będzie oddać sprawiedliwość ogromowi pracy Barcińskiego, który osiągnął niebywały cel. W ciągu piętnastu lat opublikował tyle przekładów literatury polskiej, ilu nie opublikowano w Brazylii do czasu, kiedy rozpoczął swoją działalnośćc ${ }^{34}$.

30 H. Sienkiewicz, A ferro e fogo, t. 1-2, tłum. T. Barciński, Rio de Janeiro 2004; tenże, O dilúvio, t. 1-3, tłum. T. Barciński, Rio de Janeiro 2005; tenże, O pequeno cavaleiro, tłum. T. Barciński, Rio de Janeiro 2006.

31 B. Prus, O faraó, tłum. T. Barciński, Rio de Janeiro 2012.

32 O. Tokarczuk, Os vagantes, tłum. T. Barciński, Rio de Janeiro 2014. Po Noblu ukazało się również tłumaczenie książki Prowadź swój ptug przez kości umartych. Autorką przekładu jest O. Bagińska-Shinzato: O. Tokarczuk, Sobre os ossos dos mortos, tłum. O. Bagińska-Shinzato, São Paulo 2019.

33 Gwoli sprawiedliwości dodać należy, że Kapuściński, zanim zabrał się za niego Barciński, również był tłumaczony przez innego potomka zasłużonej rodziny imigrantów polskich, który przetłumaczył Imperium (R. Kapuściński, Imperium, tłum. K. Haczynski da Nóbrega, Rio de Janeiro 1994). Niemniej to właśnie Barciński został „oficjalnym” tłumaczem Kapuścińskiego, o czym opowiada w książce Podróże z Ryszardem Kapuścińskim, część druga. Opowieści czternastu ttumaczy, Kraków 2009.

34 Uzupełniam tutaj wykaz przekładów Barcińskiego, pomijając te już wcześniej zacytowane: A. Bolecka, Querido Franz, tłum. T. Barciński, Rio de Janeiro 2002; W. Szpilman, O pianista, tłum. T. Barciński, Rio de Janeiro 2003; M. Bujko, O trem de ouro, tłum. T. Barciński, Rio de Janeiro 2007; R. Laskier, O diário de Rutka, tłum. T. Barciński, Rio de Janeiro 2008; M. Bujko, O touro vermelho, tłum. T. Barciński, Rio de Janeiro 2010; P. Huelle, Quem foi David Weiser?, tłum. T. Barciński, Rio de Janeiro 2012; T. Dołęga-Mostowicz, A extraordinária carreira de Nicodemo Dyzma, tłum. T. Barciński, Rio de Janeiro 2013. 
Kolejnym tłumaczem i badaczem, którego zasługi chciałbym tu omówić, jest niegdysiejszy podopieczny, później bliski współpracownik Siewierskiego i doktorant Jana Błońskiego, a dziś mój kolega z polonistyki UFPR, Marcelo Paiva de Souza. Jest on, jak na razie, jednym z niewielu wyjątków od reguły polskiego rodowodu wśród badaczy i tłumaczy literatury polskiej w Brazylii. Miejmy nadzieję, że z czasem, w miarę rozwoju polonistyki, de Souza okaże się nie wyjątkiem, a prekursorem pożądanej tendencji, aby tłumaczeniem i popularyzacją literatury polskiej zajęli się głównie rodzimi użytkownicy portugalszczyzny brazylijskiej (i oby byli to tak erudycyjni znawcy i użytkownicy języka jak on). Jako się rzekło, de Souza rozpoczął swoją przygodę z literaturą polską pod skrzydłami Siewierskiego, szybko jednak z ucznia stał się współpracownikiem i już podczas studiów doktorskich na Uniwersytecie Jagiellońskim - samodzielnym tłumaczem z polskiego i jednym z niewielu badaczy literatury polskiej w Brazylii. De Souza przełożył na portugalski powieści Idy Fink Podróż ${ }^{35}$ i Doroty Masłowskiej Wojna polsko-ruska pod flaga biato-czerwona ${ }^{36}$; wraz z Siewierskim odpowiedzialny jest za wzmiankowane już tłumaczenia Miłosza i Norwida, przetłumaczył również podręcznik do nauki języka polskiego ${ }^{37}$ i biografie Karola Wojtyły (wspólnie z Eduardo Nadalinem) ${ }^{38}$ oraz Andrzeja Bukowińskiego ${ }^{39}$. Bodaj najważniejszymi jednak spośród jego tłumaczeń są eseje-wykłady Miłosza zawarte w książce Świadectwo poezji ${ }^{40}$ i niezmiernie rzadkie współcześnie przekłady sztuk teatralnych, które niestety nie zostały jak dotąd opublikowane. Najczęściej przygotowywane są do inscenizacji sztuk w teatrach. Wiadomo mi, że istnieją tłumaczenia W matym dworku Witkacego, Iwony, księzniczki Burgunda Gombrowicza, Wycinki Thomasa Bernharda, zaadaptowanej przez Krystiana Lupę (tłumaczenie we współpraсу z Luizem Henrique Budantem) oraz libretta Króla Rogera Karola Szymanowskiego i Jarosława Iwaszkiewicza. Do tych przekładów należy dodać również sporządzenie napisów do dwóch filmów Andrzeja Wajdy, adaptujących na srebrny ekran dzieła Mickiewicza (Pan Tadeusz) i Fredry (Zemsta). Teatr jest od dawna obszarem zainteresowania badawczego de Souzy: już w swoim doktoracie porównywał on dzieła sceniczne Witkacego i Oswalda de Andrade ${ }^{41}$, obecnie zaś pracuje nad antologią tłumaczeń polskiego dramatu współczesnego.

35 I. Fink, A viagem, tłum. M.P. de Souza, Rio de Janeiro 1998.

36 D. Masłowska, Branco neve, vermelho Rússia, tłum. M.P. de Souza, Rio de Janeiro 2007.

37 W. Miodunka, Cześć, jak się masz? Polonês para iniciantes, Brasília 2001.

38 M. Jabłońska, Penso o que meu coração sente: obra literária e pontificado de João Paulo II, tłum. E. Nadalin, M.P. de Souza, São Paulo 2014.

39 A. Pluta, Andrés: uma vida em mais de 3 mil filmes. Biografia de A. Bukowiński, tłum. M.P. de Souza, Rio de Janeiro 2014.

40 C. Miłosz, O testemunho da poesia: seis conferências sobre as afliçöes de nosso século, tłum. M.P. de Souza, Curitiba 2012.

41 M.P. de Souza, Teatr niepokoju. Studium porównawcze dramaturgii Stanistawa Ignacego Witkiewicza i Oswalda de Andrade, Kraków 2001. 
Osobnym działem aktywności przekładowej de Souzy są jego tłumaczenia poezji publikowane w czasopismach akademickich. Oprócz wymienionych już dokonanych we współpracy z Siewierskim przekładów Miłosza i Norwida oraz również wzmiankowanych wyżej samodzielnych tłumaczeń Mickiewicza i Tuwima $^{42}$ wśród autorów przekładanych wierszy znajdujemy: Władysława Szlengla $^{43}$, Bolesława Leśmiana i Norwida ${ }^{44}$, Miłosza, Szymborską, Zagajewskiego ${ }^{45}$, Herberta $^{46}$, Różewicza ${ }^{47}$, Wata, Stanisława Grochowiaka, Karpowicza ${ }^{48}$, Józefa Barana $^{49}$ i mówiącego „przeciw poetom” Gombrowicza ${ }^{50}$. Należy tu nadmienić, że przekładom tym z reguły towarzyszą rozważania o procesie ich tłumaczenia, gdyż przekładoznawstwo należy również do centralnych tematów badawczych

42 Oprócz wymienionej powyżej pozycji z wierszami Tuwima (Tuwim, dz. cyt.) również: M.P. de Souza, Versöes de brinquedo: uma tradução brasileira dos poemas de Julian Tuwim para crianças [w:] Tradução e autoria, oprac. S. de O. Branco, M.R. da Silva Dourado, M.-H. Catherine, João Pessoa 2014, t. 2, s. 87-117.

43 M.P. de Souza, „Uma descarada janela judia”: Wtadystaw Szlengel, cronista do Gueto de Varsóvia [w:] W. Szlengel, A janela para o outro lado. „Poemas do gueto de Varsóvia”, oprac., tłum. wstęp, przypisy P. Kilanowski, Fortaleza 2018, s. 138-153 (wiersz Rzeczy).

44 M.P. de Souza, Cyprian Kamil Norwid/Bolestaw Leśmian: estranha beleza (apresentação, poemas e notas), „Revista Brasileira” 2014, t. 78, s. 303-315 (wiersze Norwida: Czutość, Syberie, Sfinks i Leśmiana: Goryl i Przed świtem).

45 Tenże, Na beleza alheia: poesia polonesa traduzida, „Belas Infiéis” 2012, t. 1, nr 1, s. 215-220 (tłumaczone wiersze to: Elegia dla N.N. Miłosza, Stówka Szymborskiej i W cudzym pięknie Zagajewskiego).

46 Tenże, Contra a música? Um poema de Zbigniew Herbert, „Contexto” 2004, nr 11, s. 211-224 (wiersz Pana Cogito przygody z muzyka); tenże, Ao vivo, direto do vale de Josafá - algumas reflexōes sobre a poesia e a tradução da poesia de Zbigniew Herbert, „Tradução em Revista (Online)" 2011, t. 1, s. 7 (wiersz U wrót doliny), tenże, O znaczeniu i godnosci tlumacza wedlug Zbigniewa Herberta [w:] Jakże samotny na niepewnej drodze! O ttumaczeniach literatury polskiej, oprac. J. Pyzia, J.M. Ruszar, Kraków-Warszawa 2019, t. 1, s. 13-32 (wiersz Colantonio. San Gierolamo e il Leone).

47 Tenże, Tadeusz Różewicz: fazer poesia depois de Oświęcim „Contexto”2019 (wiersze: Rzeź chtopców, Kazimierz Przerwa-Tetmajer, Widziatem cudowne monstrum). Również tłumaczenie wiersza Wśród wielu zajęć (szczegóły w następnym przypisie).

48 Wiersze Wata Jeśli wyraz „istnieje”..., Różewicza Wśród wielu zajęć, Karpowicza Sen otówka i Grochowiaka Czyści ukazały się jako wcześniej niepublikowane w antologii poezji polskiej, wydanej w czasopiśmie „Poesia Sempre”, która starała się udokumentować obecność tłumaczonej poezji polskiej w Brazylii, przedrukowując niektóre z tłumaczeń publikowanych od czasów Aproximaçōes wydawanej przez Siewierskiego. Antologia została opracowana przez Siewierskiego i de Souzę, a prezentuje publikowane wcześniej przekłady różnych tłumaczy i niepublikowane tłumaczenia wymienione powyżej. H. Siewierski, M.P. de Souza, A moderna poesia da Polônia (antologia), „Poesia Sempre” 2009, t. 30, s. 31-92.

49 M.P. de Souza, Resposta atrasada às cartas de Emily Dickinson, „Poesia Sempre” 2010, t. 35 (wiersz: Spóźniona odpowiedź na listy Emily Dickinson); tenże, Pura traduçäo de um lugar: em torno a uma viagem de Józef Baran [w:] Literaturas em trânsito, teorias peregrinas, oprac. I. Jasinski, Curitiba 2016, t. 1, s. 73-94.

50 W. Gombrowicz, Contra os poetas, „Poesia Sempre” 2009, t. 30, s. 21-29. 
de Souzy. Tłumaczył również z włoskiego (Jacopone da Todi) i niemieckiego (Herman Keyserling).

Pozostając w kręgu polonistów z UFPR, trzeba też wspomnieć o pracach tłumaczeniowych dwójki naukowców bezpośrednio odpowiedzialnych za to, że polonistyka mogła zaistnieć jako kierunek na uniwersytecie brazylijskim. To dzięki ich niestrudzonym staraniom, w jednym z niewielu momentów politycznie przychylnych otwarciu kierunku, okazja po temu została wykorzysta$\mathrm{na}^{51}$. Mówię tu o moim koledze Eduardo Nadalinie i o emerytowanej profesor UFPR Reginie Przybycień.

Nadalin, mimo że nie zajmuje się bezpośrednio badaniami literackimi (jest lingwista), od czasu do czasu poświęca się tłumaczeniom i w swoim dorobku ma przekład biografii Wojtyły (wzmiankowany wyżej, wspólnie z de Souza) oraz samodzielne przekłady biografii Ireny Sendler autorstwa Anny Mieszkowskiej ${ }^{52}$ i Kazania na Areopagu Wojtyły ${ }^{53}$. Przybycień, inaczej niż Nadalin, jest badaczką literatury, ale podobnie jak on jest potomkinią polskich imigrantów. To właśnie dzięki niej czytelnik brazylijski zakochał się w Szymborskiej. Pomimo że przekłady wierszy Szymborskiej mają na swoim koncie praktycznie wszyscy z tłumaczy zajmujący się poezją (zarówno zaprezentowani już Siewierski ${ }^{54}$ i de Souza, jak i Eneida Favre oraz niżej podpisany, o których za chwilę), to właśnie Przybycień udało się przekonać o wartości poetki największe brazylijskie wydawnictwo Companhia das Letras (wydało ono między innymi wzmiankowane książki Gombrowicza, Kapuścińskiego i Geremka). Po pierwszej antologii ${ }^{55}$ przyjętej (i sprzedanej) nad wyraz dobrze wydawnictwo zdecydowało się na drugi wybór wierszy ${ }^{56} \mathrm{w}$ tłumaczeniu Przybycień i po kolejnym sukcesie zapowiadany był na maj 2020 roku trzeci tomik ${ }^{57}$, tym razem

51 Oczywiście te bezpośrednie starania były poprzedzone działaniami różnych osób i środowisk (nie sposób wymienić tu wszystkich, to temat na osobny tekst, nadmieńmy zatem o ważnych działaniach Miodunki, Siewierskiego, Kawki, Leokadii Rendak i dyplomatów Jerzego Brzozowskiego i Doroty Barys).

52 A. Mieszkowska, A história de Irena Sendler: A mãe das crianças do holocausto, tłum., przypisy E. Nadalin, São Paulo 2013.

53 K. Wojtyła, Cristo, a Igreja e o mundo - catequeses do Areópago, tłum. E. Nadalin, São Paulo 2019.

54 Oprócz tłumaczeń zawartych we wzmiankowanych wydawnictwach Siewierski jest odpowiedzialny również za tłumaczenia wierszy Szymborskiej opublikowanych w czasopiśmie „Piauí". E. Ferraz, A poeta e a pedra. (poemas traduzidos por Henryk Siewierski), „Revista Piaui” 2012, nr 66.

55 W. Szymborska, Poemas, wybór, tłum., wstęp R. Przybycień, São Paulo 2011. Dla ścisłości dodać należy, że pierwsze opublikowane przez tłumaczkę wiersze Szymborskiej ukazały się w czasopiśmie „Oroboro” z Kurytyby: R. Przybycień, Wistawa Szymborska. 5 poemas, „Oroboro" 2005 , nr 4.

56 W. Szymborska, Um amor feliz, wybór, tłum., wstęp R. Przybycień, São Paulo 2016.

57 Tytuł tomiku to Para meu coração num domingo. Niestety z powodu pandemii wydawnictwo zdecydowało się opublikować gotową już książkę w terminie późniejszym, jak dotąd jeszcze niesprecyzowanym. 
we współpracy z Gabrielem Borowskim. Pomimo tego, że jak dotąd Przybycień jest tłumaczką w zasadzie jednej autorki ${ }^{58}$, jej zasługi dla popularyzacji literatury polskiej są nie do przecenienia. Szymborska w jej przekładzie na tyle przetarła drogę na rynkach wydawniczych dla literatury polskiej, że zauważalny jest wzrost zainteresowania nią zarówno wśród czytelników, jak i wśród wydawców. I dzięki tej pracy przekładowej Szymborska staje się również tematem badań, artykułów ${ }^{59}$ oraz pracy magisterskiej (z tego, co mi wiadomo, jak dotąd jedynej) $)^{60}$. Warto zauważyć, że tematy poezji Szymborskiej, jej tłumaczenia i strony feministyczne tej poezji są w centrum działalności badawczej Przybycień, która opublikowała kilka artykułów, dzieląc się rezultatami swych badań i doświadczeń translatorskich.

W tym miejscu przychodzi mi pokrótce omówić również swoje zasługi w popularyzacji literatury polskiej i jej tłumaczeń. Pomimo że tłumaczę od prawie lat trzydziestu, kiedy to zamieszkałem w Brazylii, decyzja o tym, aby te tłumaczenia wyjać z szuflady i opublikować, tak jak i czas, i motywacja na to, aby je dopracować, pojawiły się dopiero w 2009 roku, w momencie, w którym po otwarciu polonistyki w Kurytybie zostałem wraz z de Souzą jednym z wykładowców literatury na kierunku, który w zeszłym roku hucznie świętował swoje dziesięciolecie Międzynarodowym Spotkaniem Polonistycznym ${ }^{61}$. Z jednej strony publikacja tłumaczeń miała za zadanie podzielenie się materiałem, przydatnym do pracy ze studentami w momencie, w którym ich poziom polskiego nie pozwala jeszcze na lekturę w oryginale; z drugiej - tłumaczenia dwujęzyczne niewątpliwie są dobrym ćwiczeniem dla tych, którzy znają język już na tyle, aby móc porównywać; z trzeciej wreszcie, jako że zaistniała wreszcie polonistyka w Brazylii, jedną z jej misji powinno być przybliżanie kultury i literatury polskiej ogółowi społeczeństwa (ze szczególnym uwzględnieniem zainteresowanej nimi Polonii, która, niestety, często nie włada już językiem przodków).

58 Oprócz Szymborskiej przetłumaczyła również kilka wierszy Marii Pawlikowskiej-Jasnorzewskiej w antologii, która zawierała portugalskie przekłady Pawlikowskiej-Jasnorzewskiej i polskie tłumaczenia Florbeli Espanki: Diálogos no feminino. Antologia Poética Maria Pawlikowska-Jasnorzewska - Florbela Espanca, red. B. Cieszyńska, F.M. Da Silva, A. Kalewska, M.L. Dal Farra, G. Borowski, Lizbona-Warszawa 2017.

59 Jak na przykład artykuły Clarissy Loyoli Comin i Rosalii Rity Evaldt Pirolli: C.L. Comin, Apontamentos sobre corpo e resistência: análise de dois poemas de Wistawa Szymborska, „Anuário de literatura” 2017, t. 22, nr 2, s. 161-173; R.R.E. Pirolli, Trauma, lembrança e esquecimento nos poemas "Fim e começo" e "Campo da fome em Jasto” de Wistawa Szymborska, „Scripta Uniandrade" 2017, t.15, nr 3, s. 168-185.

60 N.C.G. da Costa, O poder de preservar: uma reflexão da história na poesia de Wistawa Szymborska, dissertação (mestrado) - Universidade Federal de Juiz de Fora, Pós-Graduação em Letras, Juiz de Fora, 2014.

61 Stronę internetową Kongresu i wiadomości o nim można znaleźć pod adresem: https:// www.polonistykaufpr10lat.com.br/o-wydarzeniu, dostęp: 10.04.2020. 
W tym czasie udało mi się wydać wybór rymowanek Szymborskiej ${ }^{62}$ (tłumaczenie wspólne z Eneidą Favre), dwie książkowe antologie wierszy Herberta ${ }^{63}$, wybory wierszy Szlengla ${ }^{64}$ i Irit Amiel ${ }^{65}$, a także tomiki poetyckie Odczytanie popiotów Jerzego Ficowskiego ${ }^{66}$ i Budowatam barykadę Anny Świrszczyńskiej ${ }^{67}$. Wiersze Ficowskiego i esej Marka Bieńczyka w moim tłumaczeniu ukazały się też w książce o polskich Sprawiedliwych, przeze mnie opracowane ${ }^{68} \mathrm{i}$ w wydawnictwie upamiętniającym Rok Jana Karskiego ${ }^{69}$, a fragmenty Czarnych kwiatów Norwida we wzmiankowanej już książeczce o Mickiewiczu ${ }^{70}$. Udało mi się również umieścić po trzy wiersze Szymborskiej, Herberta i Miłosza w antologii poezji światowej w przekładzie Lira argenta $^{71}$.

Wśród pozycji oczekujących na wydanie są między innymi Treny Kochanowskiego, poezje zebrane Herberta, antologie poezji Krystyny Dąbrowskiej, Świrszczyńskiej, Ficowskiego i Wata oraz opowiadania Herlinga-Grudzińskiego, Wata i Lema. Niestety, rynek wydawniczy nie inwestuje zbytnio w poezję (a jest to główny gatunek, w którym realizuję się jako tłumacz) i dość powoli przekonuje się do sprzedawalności literatury polskiej. Barciński mawiał, że $80 \%$ czasu przeznaczonego na tłumaczenie, to czas na przekonywanie wydawców. Nie mogę się z nim zgodzić w kwestiach proporcji czasowych, ale przyznaję, że jest w jego stwierdzeniu dużo prawdy. Między innymi z tego powodu staram się upowszechniać poezję polską poprzez publikacje w czasopismach. Z jednej strony zawsze jest w nich miejsce przeznaczone na popularyzację poezji, z drugiej dociera ona w ten sposób do wielu odbiorców, między innymi wydawców zainteresowanych liryką. Dość rzec, że dzięki takim publikacjom udało się

62 W. Szymborska, Riminhas para as crianças grandes, tłum., oprac., wstęp P. Kilanowski, E. Favre, Belo Horizonte 2018.

63 Dotychczas ukazały się dwie antologie Herberta w moim przekładzie, pierwsza z nich to efekt współpracy z Polonistyką Uniwersytetu Śląskiego: Z. Herbert, A viagem do Senhor Cogito/ Podróż Pana Cogito, wybór, oprac. Danuta Opacka-Walasek, P. Kilanowski, tłum. P. Kilanowski, Katowice 2016, tenże, O Senhor Cogito. Anotaçôes da casa morta, tłum. P. Kilanowski, São Paulo 2019. Wydanie już przetłumaczonych poezji zebranych oczekuje końca pertraktacji wydawnictwa ze spadkobiercami.

64 W. Szlengel, A janela para o outro lado, dz. cyt.

65 I. Amiel, Não cheguei a Treblinka a tempo, oprac., tłum. P. Kilanowski, Fortaleza 2019.

${ }^{66}$ J. Ficowski, A leitura das cinzas, tłum., oprac., wstęp P. Kilanowski, Belo HorizonteWenecja 2018.

${ }_{67}$ A. Świrszczyńska, Eu construía a barricada, tłum., oprac., wstęp P. Kilanowski, Curitiba 2017.

68 Memórias de luz: histórias de poloneses Justos, oprac. P. Kilanowski, Curitiba 2015 (wiersze Ficowskiego: ${ }^{* * *}$ (nie zdołałem ocalić) i Twoje matki obie i esej Bieńczyka Wielki narrator).

69 P. Kilanowski, C. Reiss, Jan Karski e os Justos Entre as Naçôes do Mundo, Curitiba 2014.

70 Adam Mickiewicz: um poeta peregrino, dz. cyt.

71 Lira argenta, oprac. V. Mendonça, São Paulo 2017. Opublikowane w antologii wiersze Miłosza to: Campo di Fiori, Przypowieść o maku i Biedny chrześcijanin patrzy na getto, Szymborskiej: Elegia podróżna, Psalm i Jeszcze, a Herberta: Podróz, Powrót prokonsula i Pan Cogito obserwuje $w$ lustrze swoja twarz. 
znaleźć wydawców dla Kochanowskiego i Świrszczyńskiej (Rafael Copetti Editor przygotowuje właśnie wznowienie niedawnego wyczerpanego tomiku Budowatam barykadę, wydanego poprzednio przez wydawnictwo Dybbuk). Wśród autorów, których tłumaczenia wydałem w czasopismach, są: Szymborska ${ }^{72}$, Herbert $^{73}$, Miłosz ${ }^{74}$, Ficowski $^{75}$, Świrszczyńska ${ }^{76}$, Tomasz Różyckii ${ }^{77}$, Dąbrowska ${ }^{78}$,

72 P. Kilanowski, Poemas de Wistawa Szymborska, „Qorpus” 2014, nr 13 (wiersze: Nieobecność, Seans, Mitość szcześliwa, Psalm, Mapa); tenże, Poemas de Wistawa Szymborska, „Qorpus” 2014, nr 15 (wiersze: Jeszcze i Obóz gtodowy pod Jastem); tenże, Entre a sopa de supermercado e o bingo cafona, „Suplemento Pernambuco” 2018, nr 145, 2018, s. 20-21 (limeryki, moskaliki, odwódki, lepieje, altruitki i podsłuchańce).

73 Tenże, Poesias de Zbigniew Herbert, „Qorpus” 2015, nr 19 (wiersze: Jonasz, Kaligula, O róży, Pan od przyrody, Siedmiu aniotów, Pan Cogito obserwuje w lustrze swoją twarz, Pan Cogito o postawie wyprostowanej); tenże, Poemas de Zbigniew Herbert, „Qorpus” 2017, nr 24 (wiersze: Pan Cogito - Zapiski z martwego domu, Dom, Apollo i Marsjasz, Tren Fortynbrasa, Sekwoja, Pan Cogito spotyka w Luwrze posążek Wielkiej Matki); tenże, O Senhor Cogito - o regresso, „Relevo” 2017, nr 2 (wiersz Pan Cogito - powrót); tenże, Zbigniew Herbert: uma apresentação e cinco poemas, „Suplemento Pernambuco” 2019, nr 158, s. 24-27 (Z nienapisanej teorii snów, Przestanie Pana Cogito, W drodze do Delf, Osa, Drewniana kostka).

74 Tenże, Três poemas de Czestaw Mitosz, „Qorpus” 2015, nr 15 (wiersze: Campo di Fiori, Przypowieś́ o maku, Biedny chrzésijanin patrzy na getto).

75 Tenże, Poemas de Jerzy Ficowski do livro „A leitura das cinzas”, Qorpus” 2015, nr 17 (wiersze: ${ }^{* * *}$ (nie zdołałem ocalić...); ${ }^{* * *}$ (Muranów góruje...), Twoje matki obie, List do Marc Chagalla); tenże, Jerzy Ficowski: 5 VIII 1942, „Boletim Tak!” 2017, nr 3; tenże, Carta a Marc Chagall de Jerzy Ficowski, „Suplemento Pernambuco” 2017, nr 131, s. 19-21 (wiersz: List do Marc Chagalla).

76 Tenże, A poesia contra os mitos. Notas sobre Anna Świrszczyńska, „Qorpus” 2017, nr 25 (wiersze: Strzelać w oczy cztowieka, Dwie twarze koloru żelaza, Żotnierz niemiecki, Rozmowa przez drzwi, W schronie czekając na bombę, Gdy strzelasz we mnie); tenże, As barricadas de Anna Świrszczyńska, „Suplemento Pernambuco” 2017, nr 137, s. 20-21 (wiersze: Niemiecki oficer gra Szopena, Żołnierz niemiecki, Czekam na rozstrzelanie, Marzenie harcerki, Cztowiek i stonoga, Nositam baseny); tenże, „Coragem”: os poemas femininos de Anna Świrszczyńska, „Qorpus” 2020, t. 10, nr 1, s. 130-136 (wiersze: Odwaga, Pierwsze spojrzenie, Jej brzuch, Mówi czarna kobieta, Zgrzebto z żelaza, Patrze przez oczy zalane tzami, Rodzina).

77 Wiersze Tomasza Różyckiego zostały opublikowane w czasopiśmie-blogu poetyckim, którego nazwa „Escamandro” została zainspirowana nie tylko rzeką spod Troi, ale i polską grupą poetycką: G.G. Flores, Tomasz Różycki por Rob Packer e Piotr Kilanowski, „Blogue Escamandro" 2019, https://escamandro.wordpress.com/2019/03/05/tomasz-rozycki-por-rob-packer-e-piotr-kilanowski/, dostęp: 15.04.2020 (wiersze: Cynamon i goździki, Misjonarze i dzicy, Rysy, Przeciwne wiatry, Kawa i tytoń, Nie ma końca, Mrówki i rekiny).

78 P. Kilanowski, Ao ritmo do ósseo cascalhar das castanholas, „Suplemento Pernambuco” 2019, nr 166, s. 6-7 (wiersze: Biuro podróży, Droga pszczót, Imiona, Biogramy, Rodzeństwo, *** (jesteśmy słownikiem...); tenże, ... éntre aquilo que é semelhante e aquilo que em nós é diferente...': sobre a poesia de Krystyna Dąbrowska, „Qorpus” 2010, t. 10, nr 1, s. 141-147 (wiersze: Biuro podróży, Rysunek na kamieniu, *** (jesteśmy słownikiem...), *** (nie umiem mówić my...), Bajka o jeżach, Kontrabanda; tenże, A agência de viagens de Krystyna Dąbrowska, „Revista Lavoura” 2020 (Biuro podróży). 
Wat $^{79}$, Władysław Broniewski ${ }^{80}$, Kochanowski $^{81}$, Szlengel ${ }^{82}$, Ignacy Krasicki, Leśmian, Maria Pawlikowska-Jasnorzewska, Zuzanna Ginczanka, Tadeusz Gajcy, Różewicz, Białoszewski, Krynicki, Barańczak, Kornhauser, Zagajewski, Jacek Kaczmarski ${ }^{83}$, Antoni Słonimski ${ }^{84}$, Jan Brzechwa ${ }^{85}$, Lem $^{86}$, Amiel ${ }^{87}$, Lipska ${ }^{88}$ i Josif Brodski ${ }^{89}$. W większości wypadków przekłady towarzyszyły artykułom lub esejom na temat tłumaczonych autorów bądź wierszy, a badania nad poezją polską miały jako rezultat jedyny jak dotąd doktorat, dotyczący poezji polskiej w Brazylii, poświęcony Herbertowi. Moje zainteresowania badawcze przenikają

79 Tenże, Poemas de Aleksander Wat, „Qorpus” 2017, nr 24 (wiersze: Nokturny I-IV, *** (w czterech ścianach mego bólu...). W wydawnictwie Ayiné oczekuje na publikację wybór jego wierszy i prozy.

80 L.H. Budant, Historinhas do Leste, parte 3, „Escotilha” 2018, http://www.aescotilha. com.br/literatura/contracapa/historinhas-do-leste-parte-3/, dostęp: 15.04.2020 (wiersz: Ballady $i$ romanse).

81 P. Kilanowski, Lamentos de Jan Kochanowski, „Suplemento Pernambuco” 2019, nr 161, s. 24-27 (Treny IV, V, VII, VIII, XII). Przygotowuję obecnie pełne wydanie Trenów.

82 Tenże, Wtadystaw Szlengel, Poeta do Gueto de Varsóvia, „Suplemento Pernambuco” 2018, nr 146, s. 24-27 (wiersze: Okno na tamta strone, Dwie śmierci, Mata stacja Treblinki).

83 Wiersze tych poetów i kilku innych wymienionych powyżej były częścią artykułu na temat poezji polskiej i jej tłumaczeń: P. Kilanowski, Vinte dois poetas poloneses: Uma pequena antologia de poesia em tradução, „Revista Belas Infiéis” 2020, t. 9, nr 2 s. 31-64 (wiersze i ich autorzy: J. Kochanowski, Tren V; I. Krasicki, Stowik i szczygiet; B. Leśmian, Zamyślenie; M. Pawlikowska-Jasnorzewska, Trzeba chodzić w masce; Z. Ginczanka, Zdrada; W. Szlengel, Obrachunek z Bogiem; C. Miłosz, Campo di Fiori; T. Gajcy, Święty kucharz od Hipciego; T. Różewicz, Ocalony; A. Wat *** (w czterech ścianach mego bólu...); Z. Herbert, Dwie krople; W. Szymborska, Jeszcze; J. Ficowski, Na święty nigdy; A. Świrszczyńska, Odwaga; M. Białoszewski, *** (moja głowa była Żydem...); S. Barańczak, Bo tylko ten świat bólu; J. Kornhauser, Śmierć-Żydówka; A. Zagajewski, Ogladając „Shoah” w pokoju hotelowym w Ameryce; R. Krynicki, Prawda?; J. Kaczmarski, Tunel; T. Różycki, Kawa i tytoń; K. Dąbrowska, Biuro podróży).

84 P. Kilanowski, P.S. Osório, Este da pátria minha é... A problemática do imigrante nas obras de Katarzyna Klimkiewicz, Witold Szabtowski e Pawet Huelle, „Polonicus” 2011, nr 4, s. 84-105 (wiersz: Ten jest z ojczyzny mojej).

85 P. Kilanowski, Jan Brzechwa - sobre a poesia moderna com um sorriso, „Qorpus” 2019, nr 29 (proza Jak zostać wieszczem).

86 Tenże, Stanistaw Lem - Como o mundo foi salvo, „Qorpus” 2014, nr 14 (opowiadanie Jak ocalat świat).

87 Tenże, Não cheguei a Treblinka a tempo - poemas de Irit Amiel, „Suplemento Pernambuco" 2020, nr 167, s. 18-19 (wiersze: Nie zdązytam, Film, Jona, Gabriel, Przeprosiny); tenże, 'Porque afinal precisa deixar algum rastro/ Aquele mundo completamente calcinado' Poemas de Irit Amiel, „Qorpus” 2020, t. 10, nr 1, s. 137-140 (wiersze: Nie zdążtam, Film, Ukraińska akwarela, Dybuk, Wina).

${ }_{88}$ Tenże, "Já houve uma prova de história assim". O mundo visto com ironia e pessimismo nos poemas de Ewa Lipska, „Suplemento Pernambuco” 2020, nr 172, s. 4-5 (wiersze: Egzamin, Pewność, Dzień żywych, Przestanie, Wirus, Zwątpienie, Rozum, Awaria świata, *** (Zdobądź się wreszcie na jakiś ludzki krok).

89 Brodskiego do polskiej literatury zaliczyć co prawda nie sposób, ale dla pełniejszego obrazu działalności tłumacza umieściłem tu i jego. Obecnie przygotowuję wybór jego wierszy tłumaczonych z rosyjskiego, które ukażą się w wydawnictwie Rafael Copetti Editor. 
się z działalnością translatorską. Oprócz Herberta i poezji polskiej XX wieku badam również literaturę związaną z Zagładą i tłumaczenie poezji z nią związanej, któremu się poświęcam od jakiegoś czasu; to również część projektu badawczego, w którym zajmuję się obrazem obu totalitaryzmów w literaturze polskiej.

Jak widać, wśród większości tłumaczy, którzy są nauczycielami akademickimi, działalność przekładowa ściśle przylega do badań i przenika się z aktywnością popularyzatorską.

Na koniec tych wyliczeń i w dalszym ciągu w związku z polonistyką chciałbym pokrótce przedstawić efekty inspiratorskie działań translatorskich i popularyzujących literaturę polską i wiedzę o niej. Wśród absolwentów polonistyki powoli zdobywają szlify nowi tłumacze. Niektórzy z nich jeszcze studiują, jak świetnie tłumaczący opowiadania Mrożka Matheus Moreira Pena, inni studia finalizują i w swoich pracach końcowych tłumaczą literaturę, która ma szanse być opublikowana (Medaliony Zofii Nałkowskiej przekładane przez Sarę Adrianę Voltolini czy tomik Origami Juliana Kornhausera, tłumaczony przy mojej pomocy przez Jonathana Mendesa). Jestem pewien, że przynajmniej niektórzy z nich wkrótce podążą śladami absolwentów naszej polonistyki: Luiza Henrique Budanta (drugiego obok de Souzy tłumacza bez polskich korzeni) i Favre. Budant, jak wspominałem, współpracował z de Souzą przy przekładzie Wycin$k i$, ale i samodzielnie tłumaczył między innymi Schulza ${ }^{90}$, Tuwima ${ }^{91}$, Herberta $^{92}$ i Aleksandrę Plutę ${ }^{93}$ oraz opublikował około 30 artykułów popularyzujących literaturę polską na portalu internetowym „Escotilha”.

Z kolei pierwsza absolwentka kierunku, Favre, ze swoim dorobkiem i odziedziczoną po polskich przodkach wytrwałością, już mogłaby być tematem do osobnych badań translatologicznych. Od czasu swej pracy absolutoryjnej, w której przetłumaczyła połowę powieści Michała Witkowskiego Lubiewo, Favre poświęca cały swój czas tłumaczeniom i doskonaleniu warsztatu. Współpracowaliśmy przy wzmiankowanym tłumaczeniu rymowanek Szymborskiej, ale nie tylko. Wszystkie moje tłumaczenia książkowe (i większość publikowanych w czasopismach) jak dotąd są uważnie czytane i poprawiane przez Favre; wszystkie dotychczasowe jej tłumaczenia miałem zaszczyt czytać i poprawiać. W tandemie, w którym każdy z nas dba o prawa swego języka ojczystego, udało nam

90 L.H. Budant, Carta de Bruno Schulz a Stanistaw Ignacy Witkiewicz, "Qorpus” 2014, nr 15 (tłumaczenie listu Schulza do Witkacego); L.H. Budant, „A palavra inicial era um delírio”: traduzindo „A mitificação da realidade”, de Bruno Schulz, „Qorpus” 2014, nr 15 (tłumaczenie Mityfikacji rzeczywistości wraz z esejem je omawiającym).

91 L.H. Budant, Julian Tuwim e a história da humanidade, „Escotilha” 2019, http://www. aescotilha.com.br/literatura/contracapa/julian-tuwim-e-a-historia-da-humanidade/, dostęp: 17.04.2020 (wiersz Kartka z dziejów ludzkości).

92 L.H. Budant, Historinhas do Leste, „Escotilha” 2018, http://www.aescotilha.com.br/literatura/contracapa/historinhas-do-leste/, dostęp: 17.04.2020 (wiersz: Bajka ruska).

93 A. Pluta, Ziembinski: Aquele Bárbaro Sotaque Polonês, tłum. L.H. Budant, São Paulo 2016; taż, Aquele bárbaro sotaque polonês: Ziembiński nos palcos brasileiros, Warszawa 2015. 
się stworzyć przekłady, o których sądzę, że są dobre, między innymi właśnie dzięki tej współpracy. Oprócz niepublikowanego Witkowskiego Favre przetłumaczyła również wydane w ostatnich latach Solaris Lema ${ }^{94}$, Jakbyś kamień jadta i Dzisiaj narysujemy śmierć Wojciecha Tochmana ${ }^{95}$, ogłaszane w czasopismach wiersze Szymborskiej ${ }^{j 6}$ oraz oczekujące jeszcze na druk eseje Zagajewskiego, Pocztę literacką Szymborskiej i jej biografię autorstwa Anny Bikont i Joanny Szczęsnej ${ }^{97}$, wspomnienia Haliny Birenbaum Nadzieja umiera ostatnia oraz książkę Drzewa Piotra Sochy.

Powrócę na koniec do Siewierskiego, gdyż idea wyrażona w tytule czasopisma, które redagował, jest niewątpliwie ideą przewodnią dla nas wszystkich, zarówno tłumaczy imigrantów, jak i potomków imigrantów oraz tych, którzy nie mają polskich korzeni: „Aproximaçóes”, czyli Przybliżenia lub Zbliżenia. Podobnie jak Siewierski, Łychowski, Barciński, de Souza, Nadalin, Przybycień, Favre i Budant odczuwam potrzebę przybliżania sobie dwóch światów, dwóch stron Atlantyku, dwóch ojczyzn (nawet jeżeli czasami jest to już tylko ojczyzna przodków, z którymi się identyfikujemy, lub ojczyzna olśnień, których za pomocą literatury doznaliśmy). Zbliżenie dwóch części osobowości tłumacza, związanej z dwoma językami, w których tłumacz żyje, oraz przybliżenie do tekstu oryginału - zmuszającego do bardzo bliskiej lektury, ba nawet do przyjęcia tekstu w siebie, aby go oddać w zbliżeniu - wydają się właśnie tym, co orientuje zarówno tłumaczenia, jak i sam proces badań, który wszak polega i na przybliżaniu się do tematu i na przybliżaniu go innym, czyli na budowaniu mostu między kulturami.

„Poezja buduje mosty”, jak stwierdziła Jolanta Tambor, wydając w Polsce jedyne dotąd książkowe tłumaczenie jednego z największych współczesnych

94 S. Lem, Solaris, tłum. E. Favre, São Paulo 2017. Co ciekawe, jest to pierwsze książkowe tłumaczenie Lema bezpośrednio z języka polskiego, a poprzednie były tworzone na podstawie przekładów angielskich i francuskich. Solaris w Brazylii wcześniej tłumaczono z przekładu angielskiego, który powstał na podstawie translacji na francuski (oba zresztą były bezlitośnie krytykowane przez samego Lema).

95 W. Tochman, Hoje vamos desenhar a morte, thum. E. Favre, Belo Horizonte-Wenecja 2019; tenże, Como se você comesse uma pedra, tłum. E. Favre, Belo Horizonte-Wenecja 2019.

96 Tłumaczenia były tworzone na potrzeby przekładanej biografii Szymborskiej i przed publikacją książki niektóre z nich ukazały się w czasopismach: E. Favre, Seis poemas de Wistawa Szymborska, „Qorpus” 2019, nr 29 (wiersze: *** (Nicość przenicowała się także i dla mnie...), Pochwata ztego o sobie mniemania, Odzież, Seans, Portret z pamięci, Dtoń); taż, Vou perder as violetas na pressa de ir: seleção de poemas inéditos de Wistawa Szymborska, „Suplemento Pernambuco" 2019, nr 163 s. 3-5 (wiersze: Pamięć nareszcie, Urodziny, Okropny sen poety, Nazajutrz bez nas, Każdemu kiedys); taż, Poemas de Wistawa Szymborska, „Qorpus” 2020, t. 10, nr 1, s. 113-129 (wiersze: Mata dziewczynka ściaga obrus, Wersja wydarzeń, Wczesna godzina, Tarsjusz, Trochę o duszy, Sen, Dnia 16 maja 1973 roku).

97 Wydanie książki przewidziane jest na sierpień 2020: A. Bikont, J. Szczęsna, Quinquitharias e recordaçóes. Biografia de Wistawa Szymborska, tłum., przypisy E. Favre, Belo HorizonteWenecja 2020. 
poetów brazylijskich, Paulo Leminskiego ${ }^{98} \mathrm{w}$ moim tłumaczeniu. Leminski, sam tłumacz (między innymi Mickiewicza) i jego książeczka mogą być przykładem takiego właśnie zbliżenia, jakie oferują nasze tłumaczenia. W rok po polskim wydaniu potomkowie Polaków w Brazylii, często mało już pamiętający język przodków lub uczący się go, zapragnęli poznać przekład znanego im dobrze Leminskiego na tę mowę i dzięki temu mieliśmy niezwykłą okazję, aby ponownie wydać $\mathrm{w}$ kraju brazylijskiego poety, dumnego z polskiego rodowodu, jego książkę w tłumaczeniu na polski ${ }^{99}$. Tytuł wiersza i książki Leminskiego, Powrócito moje polskie serce, okazał się wieloznaczny i niespodziewanie zaktualizowany przez opisane wydarzenie, ale może właśnie ten tytuł oddaje sens tłumaczeń i badań: dokonać niemożliwego zbliżenia, być mostem pomiędzy powracającym polskim sercem i kulturą, w której żyjemy:

powróciło moje polskie serce

serce które mój dziadek

przywiózł mi z daleka

serce zmiażdżone

serce zdeptane

serce poety ${ }^{100}$.

\section{Bibliografia}

33 wiersze brazylijskie: Carlos Drummond de Andrade, João Cabral de Melo Neto, Mario Quintana, oprac. H. Siewierski, Warszawa 2011.

Adam Mickiewicz: um poeta peregrino, oprac. H. Siewierski, Brasília 1998.

Amiel I., Não cheguei a Treblinka a tempo, oprac., tłum. P. Kilanowski, Fortaleza 2019.

„Aproximaçôes: Europa do Leste em Língua Portuguesa” 1987-1990, t. 1-4.

Ascher N., Poesia alheia. 124 poemas traduzidos, oprac., tłum. N. Ascher, Rio de Janeiro 1998.

Bolecka A., Querido Franz, tłum. T. Barciński, Rio de Janeiro 2002.

Budant L.H., „A palavra inicial era um delírio”: traduzindo „A mitificação da realidade”, de Bruno Schulz, „Qorpus” 2014, nr 15.

Budant L.H., Carta de Bruno Schulz a Stanistaw Ignacy Witkiewicz, "Qorpus" 2014, nr 15.

98 P. Leminski, Powrócito moje polskie sercel O meu coração de polaco voltou, tłum. P. Kilanowski, K. Szcześniak, Katowice 2014.

99 Tenże, Meu coração de polaco voltou - Powrócito moje polskie serce, wyd. 2 poszerz., thum. P. Kilanowski, K. Szcześniak, Curitiba 2015.

100 Tamże, s. 25. 
Budant L.H., Historinhas do Leste, „Escotilha” 2018, http://www.aescotilha.com. br/literatura/contracapa/historinhas-do-leste/, dostęp: 17.04.2020.

Budant L.H., Historinhas do Leste, parte 3, „Escotilha” 2018, http://www.aescotilha. com.br/literatura/contracapa/historinhas-do-leste-parte-3/, dostęp: 15.04.2020.

Budant L.H., Julian Tuwim e a história da humanidade, „Escotilha” 2019, http:// www.aescotilha.com.br/literatura/contracapa/julian-tuwim-e-a-historia-da-humanidade/, dostęp: 17.04.2020.

Bujko M., O touro vermelho, tłum. T. Barciński, Rio de Janeiro 2010.

Bujko M., O trem de ouro, tłum. T. Barciński, Rio de Janeiro 2007.

Comin C.L., Apontamentos sobre corpo e resistência: análise de dois poemas de Wistawa Szymborska, „Anuário de literatura” 2017, t. 22, nr 2.

Costa N.C.G. da, O poder de preservar: uma reflexão da história na poesia de Wistawa Szymborska, dissertação (mestrado) - Universidade Federal de Juiz de Fora, Pós-Graduação em Letras, Juiz de Fora 2014.

Diálogos no feminino. Antologia Poética Maria Pawlikowska-Jasnorzewska - Florbela Espanca, red. B. Cieszyńska, F.M. Da Silva, A. Kalewska, M.L. Dal Farra, G. Borowski Lizbona-Warszawa 2017.

Dołęga-Mostowicz T., A extraordinária carreira de Nicodemo Dyzma, tłum. T. Barciński, Rio de Janeiro 2013.

Favre E., Poemas de Wistawa Szymborska „Qorpus” 2020, t. 10, nr 1.

Favre E., Seis poemas de Wistawa Szymborska, „Qorpus 2019”, nr 29.

Favre E., Vou perder as violetas na pressa de ir: seleção de poemas inéditos de Wistawa Szymborska, „Suplemento Pernambuco” 2019, nr 163.

Ferraz E., A poeta e a pedra. (poemas traduzidos por Henryk Siewierski), „Revista Piauí" 2012, nr 66.

Ficowski J., A leitura das cinzas, tłum., oprac., wstęp P. Kilanowski, Belo HorizonteWenecja 2018.

Fink I., A viagem, tłum. M.P. de Souza, Rio de Janeiro 1998.

Flores G.G., Tomasz Różycki por Rob Packer e Piotr Kilanowski, „Blogue Escamandro" 2019, https://escamandro.wordpress.com/2019/03/05/tomasz-rozycki-por-rob-packer-e-piotr-kilanowski/, dostęp: 15.04.2020.

Geremek B., Os filhos de Caim. Vagabundos e miseráveis na literatura européia 14001700, tłum. H. Siewierski, São Paulo 1995.

Gombrowicz W., Contra os poetas, tłum. M.P. de Souza, „Poesia Sempre” 2009, t. 30 .

Gombrowicz W., Cosmos, tłum. T. Barciński, Rio de Janeiro 2007.

Gombrowicz W., Ferdydurke, tłum. T. Barciński, Rio de Janeiro 2006.

Gombrowicz W., Pornografia, tłum. T. Barciński, Rio de Janeiro 2009.

HerbertZ., A viagem do Senhor Cogito/ Podróż Pana Cogito, wybór, oprac. D. Opacka-Walasek, P. Kilanowski, tłum. P. Kilanowski, Katowice 2016.

Herbert Z., O Senhor Cogito. Anotaçôes da casa morta, tłum. P. Kilanowski, São Paulo 2019.

Herbert Z., Um bárbaro no jardim, tłum. H. Siewierski, Belo Horizonte 2018. 
Huelle P., Quem foi David Weiser?, tłum. T. Barciński, Rio de Janeiro 2012.

Jabłońska M., Penso o que meu coração sente: obra literária e pontificado de João Paulo II, tłum. E. Nadalin, M.P. de Souza, São Paulo 2014.

Jovanović A., Céu vazio. 63 poetas eslavos, oprac., wstęp, przypisy, tłum. A. Jovanović, São Paulo 1996.

Kapuściński R., A guerra do futebol, tłum. T. Barciński, Rio de Janeiro 2008.

Kapuściński R., Ébano, tłum. T. Barciński, Rio de Janeiro 2002.

Kapuściński R., Imperium, tłum. K. Haczynski da Nóbrega, Rio de Janeiro 1994.

Kapuściński R., Minhas viagens com Heródoto, tłum. T. Barciński, Rio de Janeiro 2006.

Kapuściński R., O imperador, tłum. T. Barciński, Rio de Janeiro 2005.

Kapuściński R., O xá dos xás, tłum. T. Barciński, Rio de Janeiro 2012.

Kilanowski P., A agência de viagens de Krystyna Dąbrowska, „Revista Lavoura” 2020.

Kilanowski P., A poesia contra os mitos. Notas sobre Anna Świrszczyńska, "Qorpus” 2017, nr 25.

Kilanowski P., Ao ritmo do ósseo cascalhar das castanholas, „Suplemento Pernambuco" 2019, nr 166.

Kilanowski P., As barricadas de Anna Świrszczyńska, „Suplemento Pernambuco” 2017, nr 137.

Kilanowski P., Carta a Marc Chagall de Jerzy Ficowski, „Suplemento Pernambuco” 2017, nr 131.

Kilanowski P., „Coragem”: os poemas femininos de Anna Świrszczyńska, „Qorpus” 2020, t. 10, nr 1.

Kilanowski P., Entre a sopa de supermercado e o bingo cafona, „Suplemento Pernambuco" 2018, nr 145.

Kilanowski P., '...entre aquilo que é semelhante e aquilo que em nós é diferente...': sobre a poesia de Krystyna Dąbrowska, „Qorpus” 2020, t. 10, nr 1.

Kilanowski P., "Já houve uma prova de história assim". O mundo visto com ironia e pessimismo nos poemas de Ewa Lipska, „Suplemento Pernambuco” 2020, nr 172.

Kilanowski P., Jan Brzechwa - sobre a poesia moderna com um sorriso, "Qorpus” 2019, nr 29.

Kilanowski P., Jerzy Ficowski: 5 VIII 1942, „Boletim Tak!” 2017, nr 3.

Kilanowski P., Lamentos de Jan Kochanowski, „Suplemento Pernambuco” 2019, nr 161.

Kilanowski P., Não cheguei a Treblinka a tempo - poemas de Irit Amiel, „Suplemento Pernambuco" 2020, nr 167.

Kilanowski P., O Senhor Cogito - o regresso, „Relevo” 2017, nr 2.

Kilanowski P., Poemas de Aleksander Wat, „Qorpus” 2017, nr 24.

Kilanowski P., Poemas de Jerzy Ficowski do livro „A leitura das cinzas”, „Qorpus” 2015, nr 17.

Kilanowski P., Poemas de Wistawa Szymborska, „Qorpus” 2014, nr 13.

Kilanowski P., Poemas de Wistawa Szymborska, „Qorpus” 2014, nr 15.

Kilanowski P., Poemas de Zbigniew Herbert, „Qorpus” 2017, nr 24. 
Kilanowski P., Poesias de Zbigniew Herbert, „Qorpus” 2015, nr 19.

Kilanowski P., "Porque afinal precisa deixar algum rastrol Aquele mundo completamente calcinado" Poemas de Irit Amiel, „Qorpus” 2020, t. 10, nr 1.

Kilanowski P., Stanistaw Lem - Como o mundo foi salvo, „Qorpus” 2014, nr 14.

Kilanowski P., Três poemas de Czestaw Mitosz, „Qorpus” 2015, nr 15.

Kilanowski P., Vinte dois poetas poloneses: Uma pequena antologia de poesia em tradução, „Revista Belas Infiéis” 2020, t. 9, nr 2.

Kilanowski P., Wtadystaw Szlengel, Poeta do Gueto de Varsóvia, „Suplemento Pernambuco" 2018, nr 146.

Kilanowski P., Zbigniew Herbert: uma apresentação e cinco poemas, „Suplemento Pernambuco" 2019, nr 158.

Kilanowski P., Osório P.S., Este da pátria minha é... A problemática do imigrante nas obras de Katarzyna Klimkiewicz, Witold Szabtowski e Pawet Huelle, „Polonicus” 2011, nr 4.

Kilanowski P., Reiss C., Jan Karski e os Justos Entre as Naçóes do Mundo, Curitiba 2014.

Kołakowski L., Sobre o que nos perguntam os grandes filósofos, t. 1, tłum. T. Łychowski, Rio de Janeiro 2009.

Kołakowski L., Sobre o que nos perguntam os grandes filósofos, t. 2, tłum. T. Łychowski, Rio de Janeiro 2009.

Kołakowski L., Sobre o que nos perguntam os grandes filósofos, t. 3, tłum. H. Siewierski, Rio de Janeiro 2009.

Laskier R., O diário de Rutka, tłum. T. Barciński, Rio de Janeiro 2008.

Lem S., Nova cosmogonia e outros ensaios, tłum., wstęp, posłowie H. Siewierski, São Paulo 2019.

Lem S., Solaris, tłum. E. Favre, São Paulo 2017.

Leminski P., Meu coração de polaco voltou - Powrócito moje polskie serce, wyd. 2 poszerz., tłum. P. Kilanowski, K. Szcześniak, Curitiba 2015.

Leminski P., Powrócito moje polskie sercel O meu coração de polaco voltou, tłum. P. Kilanowski, K. Szcześniak, Katowice 2014.

Lira argenta, oprac. V. Mendonça São Paulo 2017.

Łychowski T., Moja droga na księżyc, Warszawa 2010.

Łychowski T., Poesia da Polonia: Ewa Lipska, Ryszard Krynicki „Revista Brasileira” 2016, t. 89.

Masłowska D., Branco neve, vermelho Rússia, tłum. M.P. de Souza, Rio de Janeiro 2007.

Memórias de luz: histórias de poloneses Justos, oprac. P. Kilanowski, Curitiba 2015.

Mieszkowska A., A história de Irena Sendler: A mãe das crianças do holocausto, tłum., przypisy E. Nadalin, São Paulo 2013.

Miłosz C., Não mais, wybór, tłum., wstęp H. Siewierski, M.P. de Souza, Brasília 2003.

Miłosz C., O testemunho da poesia: seis conferências sobre as aflições de nosso século, tłum., wstęp M.P. de Souza, Curitiba 2012. 
Miłosz C., Różewicz T., Szymborska W., Herbert Z., Quatro poetas poloneses, tłum., wstęp H. Siewierski, J.S. Naud, Curitiba 1994.

Miłosz C., Różewicz T., Szymborska W., Krynicki R., Herbert Z., Versos polacos, tłum. M.T. Bação Fernandes, F. Menezes, M.C. Correia, C.S. Pereira, H. Siewierski, Lisboa 1985.

Miodunka W., Cześć, jak się masz? Polonês para iniciantes, Brasília 2001.

Norwid C.K., O piano de Chopin, tłum. H. Siewierski, M.P. de Souza, Brasília 1994.

Pessoa F. Przestanie, tłum. H. Siewierski, A. da Silva, Warszawa 2006.

Pirolli R.R.E., Trauma, lembrança e esquecimento nos poemas „Fim e começo” e „Campo da fome em Jasto” de Wistawa Szymborska, „Scripta Uniandrade” 2017, t. 15, nr 3.

Pluta A., Andrés: uma vida em mais de 3 mil filmes. Biografia de A. Bukowinski, tłum. M.P. de Souza, Rio de Janeiro 2014.

Pluta A., Aquele bárbaro sotaque polonês: Ziembiński nos palcos brasileiros, Warszawa 2015.

Pluta A., Ziembinski: Aquele Bárbaro Sotaque Polonês, tłum. L.H. Budant, São Paulo 2016.

Prus B., O faraó, tłum. T. Barciński, Rio de Janeiro2012.

Przybycień R., Wistawa Szymborska. 5 poemas, „Oroboro” 2005, t. 4.

Sapkowski A., A espada do destino, tłum. T. Barciński, São Paulo 2012.

Sapkowski A., A senhora do lago, t. 1, tłum. O. Bagińska-Shinzato, São Paulo 2017.

Sapkowski A., A senhora do lago, t. 2, tłum. O. Bagińska-Shinzato, São Paulo 2017.

Sapkowski A., A torre de andorinha, tłum. O. Bagińska-Shinzato, São Paulo 2016.

Sapkowski A., Batismo de fogo, tłum. O. Bagińska-Shinzato, São Paulo 2015.

Sapkowski A., O sangue dos elfos, tłum. T. Barciński, São Paulo 2013.

Sapkowski A., O último desejo, tłum. T. Barciński, São Paulo 2011.

Sapkowski A., Tempo de tempestade, tłum. O. Bagińska-Shinzato, São Paulo 2019.

Sapkowski A., Tempo do desprezo, tłum. T. Barciński, São Paulo 2014.

Schulz B., Ficção completa, tłum., posłowie H. Siewierski, São Paulo 2012.

Schulz B., Lojas de canela e outras narrativas, tłum. H. Siewierski, São Paulo 2019.

Schulz B., Lojas de canela, tłum. H. Siewierski, Rio de Janeiro 1996.

Schulz B., Sanatório, tłum. H. Siewierski, Rio de Janeiro 1994.

Sienkiewicz H., A ferro e fogo, t. 1-2, tłum. T. Barciński, Rio de Janeiro 2004.

Sienkiewicz H., O dilúvio, t. 1-3, tłum. T. Barciński, Rio de Janeiro 2005.

Sienkiewicz H., O pequeno cavaleiro, tłum. T. Barciński, Rio de Janeiro 2006.

Siewierski H., História da Literatura Polonesa, Brasília 2000.

Siewierski H., Jak dostatem Brazylię w prezencie, Kraków 1998.

Siewierski H., Souza M.P. de, A moderna poesia da Polônia (antologia), „Poesia Sempre" 2009, t. 30.

Silva F.R. da, Zaleski R.T.T., Estado Novo, campanha de nacionalização e a restrição nos processos de sociabilidade étnica entre os polono-brasileiros no Sul do Brasil: União das Sociedades Oswiata, „Revista Semina” 2017, t. 16, nr 2. 
Souza M.P. de, Ao vivo, direto do vale de Josafá - algumas reflexóes sobre a poesia e a tradução da poesia de Zbigniew Herbert, "Tradução em Revista (Online)” 2011, t. 1 .

Souza M.P. de, Contra a música? Um poema de Zbigniew Herbert. „Contexto” 2004, nr 11.

Souza M.P. de, Cyprian Kamil Norwid/Bolestaw Leśmian: estranha beleza (apresentação, poemas e notas). „Revista Brasileira” 2014, t. 78.

Souza M.P. de, Na beleza alheia: poesia polonesa traduzida. „Belas Infiéis” 2012, t. 1, nr 1 .

Souza M.P. de, O znaczeniu i godności ttumacza wedtug Zbigniewa Herberta [w:] Jakże samotny na niepewnej drodze! O ttumaczeniach literatury polskiej, oprac. J. Pyzia, J.M. Ruszar, Kraków-Warszawa 2019, t. 1.

Souza M.P. de, Pura tradução de um lugar: em torno a uma viagem de Józef Baran [w:] Literaturas em trânsito, teorias peregrinas, oprac. I. Jasinski, Curitiba 2016, t. 1 .

Souza M.P. de, Resposta atrasada às cartas de Emily Dickinson, „Poesia Sempre” 2010, t. 35.

Souza M.P. de, Tadeusz Różewicz: fazer poesia depois de Oświęcim „Contexto” 2019.

Souza M.P. de, Teatr niepokoju. Studium porównawcze dramaturgii Stanistawa Ignacego Witkiewicza i Oswalda de Andrade, Kraków 2001.

Souza M.P. de, Uma descarada janela judia": Wtadystaw Szlengel, cronista do Gueto de Varsóvia [w:] W. Szlengel, A janela para o outro lado. Poemas do gueto de Varsóvia, oprac., tłum., przypisy, wstęp P. Kilanowski, Fortaleza 2018.

Souza M.P. de, Versóes de brinquedo: uma tradução brasileira dos poemas de Julian Tuwim para crianças [w:] Tradução e autoria, oprac. S. de Oliveira Branco, M.R. da Silva Dourado, M.-H.C. Torres, João Pessoa, 2014, t. 2.

Szczypiorski A., A bela senhora Seidenman, tłum. H. Siewierski, São Paulo 2007. Szczypiorski A., Uma missa para a cidade de Arras, tłum. H. Siewierski, São Paulo 2001.

Szlengel W., A janela para o outro lado. Poemas do gueto de Varsóvia, oprac., tłum., przypisy, wstęp P. Kilanowski, Fortaleza 2018.

Szpilman W., O pianista, tłum. T. Barciński, Rio de Janeiro 2003.

Szymborska W., Poemas, wybór, tłum., wstęp R. Przybycień, São Paulo 2011.

Szymborska W., Riminhas para as crianças grandes, tłum., oprac., wstęp P. Kilanowski, E. Favre, Belo Horizonte 2018.

Szymborska W., Um amor feliz, wybór, tłum., wstęp R. Przybycień, São Paulo 2016.

Świrszczyńska A., Eu construía a barricada, tłum., oprac., wstęp P. Kilanowski, Curitiba 2017.

Tochman W., Como se você comesse uma pedra, tłum. E. Favre, Belo HorizonteWenecja 2019.

Tochman W., Hoje vamos desenhar a morte, tłum. E. Favre, Belo HorizonteWenecja 2019.

Tokarczuk O., Os vagantes, tłum. T. Barciński, Rio de Janeiro 2014. 
Tokarczuk O., Sobre os ossos dos mortos, tłum. O. Bagińska-Shinzato, São Paulo 2019.

Tryzna T., Senhorita Ninguém, tłum. H. Siewierski, Rio de Janeiro 1999.

Tuwim, oprac. A. Drewno, Warszawa 2013.

Wojtyła K., Cristo, a Igreja e o mundo - catequeses do Areópago, tłum. E. Nadalin, São Paulo 2019. 